[Upsall, D. (2004). Shared Principalship of Schools. New Zealand Annual Review of Education, 13, 143-168]

\section{Shared Principalship of Schools}

\section{DEBBY UPSALL}

\section{Abstract:}

Since the Tomorrow's Schools reforms of 1989 decentralised school administration, a managerialist construct of leadership has been officially promoted. It will be aroued that this approach to school leadership has been at odds, not only with the beliefs and preferred practice of the majority of New Zealand primary school principals, but also with the recommendations of a wealth of national and international educational researchers and theorists. Collaborative management structures are not only an effective way of leading successful schools, but may attract into school leadership a wider variety of applicants. New Zealand primary schools are currently experiencing increasing difficulty recruiting new principals and retaining experienced ones. Alternative models of school principalship that might make the job more manageable and attractive, particularly to women, need to be explored. One such alternative model, shared principalship, is discussed.

$\mathrm{F}$ rom 1989, the radical restructuring of educational administration, known as the Tomorrow's Schools reforms, took place in New Zealand. Whether the changes actually constituted "reform" in the sense of "improvement", has since been widely debated in New Zealand educational literature. One thing is clear. Individual school principals bore the brunt of the changes, and many have argued that these changes took the focus of the individual school principal away from "the heart" of the job - educational leadership - to focus instead upon managerial concerns. The role of principal was to become pivotal to the success or failure of a school, to an extent it had not been before. The consequential increase in their workload, as well as the changing nature of their work, has been well documented by a series of surveys, conducted over a decade by the New Zealand Council for Educational Research (Wylie, 1989, 1991, 1992, 1994, 1997a, 1999).

\section{Debby Upsall}

The need for a principal to be almost "superhuman" in order to cope with these new demands is an issue for both women and men aspiring to school leadership. Contradictory discourses valuing "a balanced life" or "life outside work", set against those promoting selfless dedication to the job, leave many potential principals feeling that if they choose to apply for a principal's position they are choosing to give up the enjoyment of family life and other interests.

Although women comprise a large proportion of the teaching profession this is not reflected in the number of women in leadership positions in schools. Of all the men employed in state sector primary and intermediate schools, 43 percent are in management positions and 26 percent are principals. Of the women, 22 percent are in management positions and only 4 percent are principals (Ministry of Education, 2002, March). Despite equal opportunity legislation, there appears to have been very little improvement in the situation since 1984, when the Teacher Career and Promotion Study (Norman, 1985) found that only 2.1 percent of women employed in state sector primary and intermediate schools were principals.

The changes in educational administration since 1989 may have made it even less likely that newly appointed principals are women. Not only has the nature of the job changed, and become more stressful, but boards of trustees now have the sole responsibility for selecting their principals. The attitudes of boards of trustees towards women applicants is another un-researched but probably significant factor affecting the proportionately low number of women principals. Even the Education Review Office (ERO), in its report entitled Professional Leadership in Primary Schools (1996), admitted that there could be a problem of inequality when it comes to principal appointments: "Given that a high proportion of teachers are women, the failure to appoint them to principal positions is likely to indicate that factors other than the best person for the job are influencing board of trustee appointments" (p. 9). Surprisingly, this issue of possible gender discrimination in principal appointments was not investigated in ERO's later study The Appointment of School Principals (2001). ${ }^{1}$

Commenting on parallel market-driven changes in British schools, Grace (1995) observed that the "intensification" of headteachers' workloads was contributing to making the job increasingly less attractive to women. Traditionally women have been the ones to take the bulk of the responsibility of child rearing and household tasks in 
the home, as well as caring for older family members. They are also more likely than men to be involved as volunteers in various community groups, school and kindergarten fundraising committees, and the like. Historically, women teachers who are also mothers with family responsibilities have been reluctant to take on the additional load associated with being a school principal. However, the increasing availability of childcare, together with the efficacy of contraception and the changing attitude of some men towards their partner's careers, is freeing some women to seek promotion to principals' positions. But it is still primarily the single and childless among women who apply (Grant, 1989; Limerick, 1995).

Job sharing is increasingly gaining favour among women as a way in which they can have both a family and a career. Many schools have shared teaching positions, but the idea that a principal's job can be shared is still relatively rare, however. The "mana" of the principal's position, together with the traditional, masculinist hierarchical conception of the need to have a strong, dominant individual "at the top" of a school, militates against a "co-principalship" model. The Ministry of Education, tasked with implementing the Education Act (1989) does not favour the concept for accountability reasons, arguing that it specifies that a school shall have "a principal" who is accountable for what happens in a school, meaning only one.

In spite of this, some schools have experimented with shared principalships. In one school a co-principalship has been operating successfully since 1993. Does sharing the job make it more manageable? Is this an option that could open up to a wider range of people the challenges and rewards of a principal's job without the seemingly inevitable stress and risk of burnout? Should shared principalship be investigated by the Ministry of Education as an option for school leadership? This article aims to review the issues, and will attempt to provide some directions for the future.

\section{Historical Background}

The role of the school principal today needs to be examined in the context of the Tomorrow's Schools reforms, following the publication of the Picot Report, Administering for Excellence (Department of Education, 1988). This had much to say about the need for partnership between the professional and the community, about cooperation, participation and local responsibility. The principal was described as a professional leader using collaborative strategies to inspire enthusiasm and commitment from the teaching staff.

The subsequent Lough report, Today's Schools (Ministry of Education, 1990), was a review of the reforms, set up as a result of pressure from Treasury and the State Services Commission, which were "anxious to review progress and make corrections" (Butterworth, 1998, p. 160). Despite following so soon after Administering for Excellence, it was a quite different document, permeated by the current managerialist language, such as "educational outputs" and "key performance indicators". The principal's role was now "to support teachers ... by identifying areas of skill deficiency and making available appropriate training to correct these deficiencies" (p. 24). Not surprisingly, there was a strong reaction to this report by many principals, who held it to be antithetical to their beliefs and principles (Sullivan, 1994).

The juxtaposition between the ideals as expressed in the Picot Report and the so-called "New Right" agenda of external accountability and hierarchical control led to contradictions and confusion (Aiken, 1994; Palmer, 1997; Rae, 1999; Robertson, 1995; Trenberth, 1996). The development of a system of performance management for schools along with professional standards for teachers and principals pushed principals further into a managerial role. They were now responsible for evaluating teacher competence for salary progression as well as registration. Codd saw these developments in terms of a "fundamental change in ... ethos", labelling it a "culture of distrust"; "...in the pursuit of greater accountability, government policies have fostered within educational institutions a culture in which trust is no longer taken to be the foundation of professional ethics" (1999, p. 45).

It would appear that a rhetoric of partnership and empowerment of schools and communities masked an agenda of tightening central control and a focus upon accountability. The role of school principal changed from one of professional leader of a school to one of chief executive of an organisation.

\section{The Paradox of the Principal's Role}

The contrast between the collaborative professional leader envisaged by the Picot committee, and the managerial authoritarian model advocated by the Lough committee, was to epitomise the confusion as 
to the principal's role in New Zealand schools throughout the years 1989-2003. A succession of resources explaining the roles of school boards of trustees and principals supplied by the Ministry of Education to boards during this period was clothed in managerial language and concepts. For example, Professional Leadership in Primary Schools (Education Review Office, 1996, p. 15) stated, "A core competency expected of principals is the ability to achieve client satisfaction and manage the school's external interface." Robertson (1995) labelled the years 1990-1995 "an era of contradictions, compromises, dichotomies and dilemmas" for principals (p. 7). She criticised the growing emphasis on the management role of the principal at the expense of the professional leadership role. These concerns were echoed by other researchers into school principalship in New Zealand, such as Strachan (1997), Trenberth (1996) and Palmer (1997). As Palmer observed, this conflict between the management and professional roles of principals generated extra stress.

In Britain, a similar trend has been observed over the period. Grace wrote, "Contemporary developments in educational policy have accentuated the culture of busyness in schools (work intensification) at the expense of a culture of reflection" $(1995$, p. 68). An article in the Education Guardian (Curtis, 2002) notes that British schools are currently experiencing a critical shortage of people willing to take on head teacher posts, largely because of a perception of the workload burden and "over-accountability" involved.

Even as recently as 2002, New Zealand principals were receiving mixed messages from the Ministry and its agencies. A booklet of guidelines for boards of trustees on performance appraisal of principals published that year started by encouraging appraisal which "goes beyond compliance and accountability and encourages reflection, innovation, risk taking, creative leadership and professional growth." But it finished by stating, "Good practice schools have moved beyond just debating the issues ...[to] get on with improving rigour, avoiding capture, [and] complying with national standards." (Education Review Office, 2002, p. 22).

\section{Leadership Versus Management}

The terms "leadership" and "management" are used to describe aspects of a school principal's job, but are often confused with one another.
School management is generally held to mean those routine administrative tasks that ensure the smooth day-to-day operation of an institution. It focuses on carrying out policy and staying within a budget, and the school is viewed as a business to be run efficiently.

School leadership, in contrast, is about moral values, educational values, and professional principles (Grace, 1993). It focuses on long term goals, on inspiring and supporting teachers to pursue best practices in teaching and learning. The school is viewed as a collection of people with a common goal of improving educational outcomes.

Some of the literature treats leadership and management as distinct and to some extent competing concepts (Nowlan, 2000; Snook, 1990; Sullivan, 1992; Thurman, 1969) whereas other writers regard them as complementary concepts that should not be considered separately, but kept in balance (Robertson, 1995; Sergiovanni, 1991, 2001; Stewart, 2000; Wylie, 1997). For example, Flockton (2002) has commented:

In some schools the principal is now first and foremost an office manager; fortunately there are others where the principal is indisputably the professional leader, whose major focus is on knowing, supporting and guiding people. There's a big difference. The ideal principal knows where to draw the line between management and leadership, accepting that both are legitimate and often intertwined functions.

A principal's influence over his or her school takes place through responding to a multitude of often seemingly mundane tasks and everyday interactions, but these responses are shaped by a mixture of professional knowledge, intuition based on experience, and reflection about what is best for the school (Sergiovanni, 1989). Soon after the reforms were implemented, Snook warned of the danger of management burdens overwhelming principals and advised, "You must make leadership your priority and delegate as much as you can of everything else" (1990, p. 7). But there is no doubt that in recent years management tasks have multiplied, and responsibility for more and more has fallen to the principal.

\section{Priorities for Principals}

The changes that had occurred in the role of the primary school principal since 1989 were analysed by Wylie, using survey, discussion and interview data (1997b). She found that although administrative 
work had increased exponentially since the reforms, educational leadership was still considered by principals to be the most important aspect of their role. This appears to be at odds with what she terms "the official view" as outlined in Professional Leadership in Primary Schools (Educational Review Office, 1996), which compares the role of the primary school principal with a senior public servant and the manager of a private business:

The bottom line for a manager of a private firm is profit and staying in business. The bottom line for a principal is roll numbers and keeping the school viable.

Managing a school, a private business or a government agency involves developing strategies, determining goals, providing means to achieve them, using resources efficiently, managing people and ensuring the quality of outputs."(p. 10)

For most school principals, "the bottom line", that by which they measure their success in the job, is not roll numbers or financial management, but the satisfaction of teaching and working with students and staff (Wylie, 1999, p. 112). David Stewart, the former head of the New Zealand Principal and Leadership Centre at Massey University, has also criticised this definition of the traits of a successful principal, as advocated by the Ministry of Education. In commenting on how important it is for principals to get their priorities right, he notes: "If you focus on educational issues, the management things get done to support the educational things. But if you focus only on managerial things, it's possible that many of the important educational things get left undone" (Rourou, 2001, p. 7).

\section{Collaborative Leadership}

The concept of the principal sharing leadership power and authority is central to theories of collaborative leadership that have been in vogue since the 1980s. They were implicit in the Picot report (Cardno, 1990 , p. v), but were antithetical to a managerialist construct of hierarchical power with all authority embedded at the top. There exists a wealth of research into (and writing about) school leadership that suggests that collaborative leadership models are more likely to be successful at improving school effectiveness. ${ }^{2}$

A group of 50 principals interviewed by staff of the Educational Review Office (1996) regarded collaborative ways of working with their staff as necessary to good management. These included:
- $\quad$ providing feedback mechanisms

- delegating responsibilities

- consulting and reaching consensus

- trusting and respecting staff, and

- using democratic and highly visible personnel procedures.

However, ERO appeared not to be entirely happy with this definition of staff management, and commented, "These competencies of successful staff management present a challenge to the principal in achieving school goals and meeting the board's vision ... there will be times when the principal may need to override consensus decisions or democratic processes of staff members in order to deliver what the board of trustees requires" (1996, p. 18).

Sergiovanni presents an opposing viewpoint. He suggests that "leadership density", meaning the spread of leadership amongst the entire staff of the school, is more significant than principal leadership in establishing successful schools (2001, p. 162). Grace (1995), too, advocates more democratic school cultures and leadership styles, arguing that "intelligent and active participation in political and civic life must be the primary aim of schooling" (p. 199) and that "if democratic culture is to be renewed and strengthened, then schooling itself must be permeated by appropriate democratic practice" (p. 200). He goes on to argue that more democratic forms of school leadership can also relieve workload pressures on school leaders.

Similar conclusions were reached by Capper (1994), as a result of an action research project into shared decision-making in twelve schools conducted on behalf of the PPTA (Post Primary Teachers' Association). Not only could shared decision-making structures and processes "alleviate workload pressures on workers" (p. 39), but they could also "provide students with immersion into a truly democratic sub-society" (p. 93).

Given this ongoing debate, it may seem surprising that the concept of shared leadership is not more widely discussed and practised in New Zealand. One explanation is that the educational reforms since 1989 have moved to strengthen hierarchical structures and consolidate power in the boards of trustees, the principal, and the review agencies. The research of Court $(1998,2001)$ describes how the increasingly managerialist approach to school leadership issues by New Zealand educational officialdom has put obstacles in the path of schools wishing to pursue the option of shared principalship. 
Overseas, in the United States, Canada, Britain, the Netherlands, and Norway, Court found a wide variety of approaches to shared leadership. "Headless schools", where the principal's responsibilities are shared throughout the entire staff, have even been experimented with in California (Barnett et al, 1998; San Francisco Unified School District website, 1996), in Minnesota, Norway and New Zealand (Court, 2001, 2002, 2003a, 2003b).

Steiner schools have traditionally been led by a teacher collective, the "College of Teachers". It was only to gain government funding as "integrated schools" that New Zealand Steiner school staffs began to nominate one of their number as "principal" to meet the Ministry of Education requirement that one individual in each school be ultimately accountable. As the website of the Christchurch Rudolf Steiner School observes, "Most integrated Rudolf Steiner/Waldorf schools attempt to blend these two distinct and contradictory requirements by adopting some sort of shared principalship, and to provide for the rotation of the person appointed as Principal amongst the group who share the principalship role" (Glynn, 2002).

\section{Shared Principalship}

"Distributed leadership", referring to different ways of sharing the load of leadership, is a phrase currently in vogue in Britain (Gronn, 2002) and was the "hottest issue" at the recent British Educational Research Association conference, according to Piggot-Irvine, with "co-principalship being at the top of the list" (2003, p. 2).

Courtinvestigated international examples of co-principalships and found there were a range of approaches to shared leadership. These included:

- full-time, task-specialised co-principalships

- full-time, supported dual leaderships

- part-time, job-sharing partnerships

- integrative co-headships

- teacher leadership collectives (Court, 2003a, p. 8).

She outlines a number of advantages of shared leadership. For the co-principals, reduced isolation and stress, together with enhanced professional development, stimulation and enjoyment were cited. For schools, advantages include an increased skill resource, better decisions, more completed projects, and improved professional supervision. Teachers in these schools also reported increased opportunities for professional development and leadership, better control over issues that affect them, increased individual commitment to responsible management of resources, and improved staff morale (p. 34).

The investigation by Brooking and colleagues of the recruitment "crisis" in New Zealand primary schools suggests that shared school leadership initiatives may be part of the solution, encouraging into principalship or retaining in principalship

- teachers who aspire to leadership, but want professional collegiality and support as they begin in a principalship or leadership team;

- aspiring or practising principals who need to find viable ways to "juggle" family, study and career commitments;

- experienced principals who are contemplating early retirement because of burnout;

- experienced principals who are looking for fresh ways to contribute to the development of other professionals' talents and leadership potential (2003, pp. 13-14).

An internet search reveals many references to co-principalships in American schools, where this option is being used in a variety of ways. The trend towards very large schools is being accompanied by a trend to have more than one principal, to manage the workload (Keeler, 1998; Laughlin, 2002). Tired, "burnt-out" principals are being encouraged to stay in the job by being given a co-principal (Eggert, 2002). Women are able to job-share the principalship so they can spend more time with their families (Brown \& Feltham, 1997). Principals who are faced with losing a deputy principal they value are being able to offer them the opportunity to move into a co-principalship in order to retain their skills and knowledge (Cromwell, 2002). Schools are appointing two principals in order to divide the principal's workload and make the job more attractive and manageable (Bell, 2001). In a climate when student academic results are crucial to the success of a school, the job can be divided so that one co-principal has responsibility for pushing up student achievement (Kim, 2001). Bilingual and immersion schools are able to appoint a native speaker as co-principal (Wolffe, 2001). An experienced principal moving on to another school is able to mentor a new principal into taking over her 
school (Gonzales, 2003). Co-principalship is being suggested as a way of making the principal's job less isolated and of attracting new people into the job (Hopkins, 2003).

\section{Co-principalship in New Zealand}

The first co-principalship established in New Zealand was at Selwyn College in 1992. Carol White and John Kenny were both deputy principals at Selwyn College when the principal became seriously ill. They ran the school between them and were so successful that when the principal retired, they decided to apply for the job together. Neither wanted to do the job alone, seeing it as "an unreal burden" for one person.

The research of Glenny and colleagues (1997) into this co-principalship describes a school which had changed its culture as a result of "power-sharing at the top". Equity, participation and accessibility were described as the features of this new culture. "Because all individuals are regarded as having equal value in the school community, a sense of personal empowerment is embodied in the school's value system", they write (p. 4). They believed that the example of Selwyn College "should inspire others to look at the advantages of having two at the top"(p. 1).

When John Kenny retired in 2000, Carol White took over the principalship on her own, but found the co-principalship model so much preferable that at the end of 2002 she entered into negotiations with the board of trustees to re-establish a co-principalship with her deputy of the past two years (telephone interview, Nov, 2002).

Asked why she thought so few other schools had taken up the co-principalship model, White theorised that it is socialised into men to want to be a "strong leader", and to "do it alone", believing that "you haven't really made it" (i.e., achieved success in your career), unless you are "at the top", a principal. She herself felt that she had more credibility now that she had proved that she could "do it alone", but believed that she could do a better job with a co-principal to share the load. This did not mean that her workload would be any less, she emphasised, but that feelings of isolation and stress, of having to be an expert at everything, would be reduced.

Co-principalships have received some positive official recognition in two different contexts in the New Zealand Gazette. In July 2003, the co-principals of Mountain View primary school were featured after they had won the 2002 Goodman Fielder School of the Year award, and the article observed, "Collaboration seems to be integral to this top school's success. The principals describe their unique bicultural co-principalship as an "amazing synergy" that improves learning in both Maori and English" (West, 2003).

In May 2002, the Gazette featured a co-principalship at Manawatu College, stating that this arrangement reduced the sense of loneliness and isolation that often goes with a principal's job. The article also claimed that having a co-principalship meant that bigger projects could be tackled, and jobs completed faster and more thoroughly (Stewart, 2002). This co-principalship has also featured in an Equal Educational Opportunities (EEO) publication (Brooking, 2002) as an example of a way of encouraging women into senior management, and of achieving gender balance in management.

Karen Anderson, a former co-principal of Manawatu College who spent four years in that position, has emphasised what a "powerful model" co-principalship is, and how she believed it had the potential to make a "huge difference to what's happening in schools". Her experience was that two principals working together could achieve much more than one on their own. She also felt that it was "extremely developmental professionally" for the co-principals, particularly in the area of crisis management: "You could sit down and thrash it out together ... not being alone, not having to carry the burden of the moral responsibility all the time was really good." It was her view that the Ministry of Education ought to be encouraging schools to move to co-principalships, but believed that the reasons they tended to be "obstructive" were twofold - fear it could cost them more money, and their insistence that there be just one person in a school who is legally accountable (telephone interview, 2003).

\section{Women As School Leaders}

Some researchers have suggested that many women choose not to seek principals' positions because they place higher value on spending time with their families, leisure interests, or most commonly, teaching itself (Giles, 1995; Hall, 1997; Ozga \& Walker, 1995; Shakeshaft, 1987). For Karen Anderson, being offered the opportunity to move into a co-principalship made the job manageable; "I really wanted to be a principal, and I think it would have been a lot more difficult for me to pursue that dream at that time of my life, in my mid- to-late $40 \mathrm{~s}$, 
because of the age of my kids and my determination not to compromise on my role as a Mum" (telephone interview, 2003).

Women have been criticised for lacking aspiration, and not applying for principals' positions, though according to Brooking and colleagues, this is a "popular myth" $(2003$, p. 8). Certainly, some of Livingstone's (1999) survey respondents commented that for every successful application of a woman for a principal's position, there were many unsuccessful applications (pp. 81-83). This raises the possibility already alluded to that boards of trustees may be discriminating against women applicants for such positions.

For many women teachers, however, it is a case of aspiring to be a great teacher, rather than not aspiring to be a principal. Since the principal's job is seen as something quite different, something that would take them out of the classroom, they don't want it. Shakeshaft commented that men don't start careers in education with the same commitment as women. For many of them it is their second choice of career or seen as temporary, whereas for most women teachers, it's "what I always wanted to do" (1987, pp. 70-71). Working within a co-principalship, however, can mean that a principal is able to spend more time in the classroom.

Many teachers, not only women, are uncomfortable with hierarchical leadership structures, which can work against a school educational culture of empowering, nurturing, learning and developing (Capper, 1994; Grace, 1995; O’Neill, 1999; Robertson, 1995). Court describes schools as "pyramids of communication and control", with the principal maintaining "an independent overview from a position at the head of various lines of command" (1994, p. 12). But many women don't want to be at the top of a hierarchy, telling people what to do. Al Khalifa states that many women see hierarchical management practices in schools as "repugnant or dis-functional" (1989, p. 89).

Some "feminist" research into leadership has ascribed to an "essentialist" view of women the notion that women are inherently suited to collaborative leadership contexts. But Acker argues that any discussion of women's styles of leading must be wary of focusing on the "sameness" of women and by implication their difference from men. There is "much diversity among women and by emphasising sameness, we downplay diversity" (1999, p. 290). Court criticises this "cultural feminism" approach as "oppositional" (2003c); Blackmore described it as "constraining and disempowering" as well as "dangerous" (1999, pp. 57-58). The danger is that it can lead to reverse sexism, idealising "feminine values"; it can limit women's options to behave in different ways; it can idealise the selfless, powerless woman; it can deny the powerful shaping influences of social practices by accepting them as "natural". Smulyan (2000) found women principals were constantly struggling to balance what others expected from a leader and what they expected from a woman.

Co-principalships offer those people who reject hierarchical leadership structures the opportunity to introduce new, flatter management structures into their schools. A collaborative management structure is more relevant to "the actual working priorities of the school" (O'Neill, 1999, p. 87). Principals who encourage and help teachers to work together are more likely to develop a sense of community and a positive learning environment in their schools. Having more leaders in schools using more inclusive and collaborative leadership practices also has the potential to enhance community involvement.

\section{Some Recent Research}

During 2002-2003, I conducted a small research case study of four quite different co-principalships, to explore ways in which sharing the principal's job impacted upon a principal's workload (Upsall, 2003). Two of the schools were large urban schools, one a decile $1 \mathrm{a}$ and the other a decile 5 Catholic integrated school. Each of these had two women co-principals. The third school was a small central city school with only three teachers, all women, who shared the co-principalship. The fourth was a new school in a growing suburban area which had a unique management structure comprising four schools within one school, each with its own teaching principal, with a "floating" principal in addition.

The case study should be of particular interest to the many teaching principals in New Zealand schools. Many of those in Livingstone's (1999) survey commented that they felt their classroom practice suffered because they were forced to spend too much time on administrative tasks. An important advantage to some co-principals in this study - and not just the teaching co-principals - was that a co-principalship reduced the amount of time they had to spend in the office, so they could spend more time in the classroom. 
For the co-principals in the larger schools, sharing their job meant more time for family and other interests. Those who had established their co-principalship with the intention of reducing their workload had been largely successful in doing so. Those who had set them up for more philosophical reasons were able to concentrate on developing their vision for their school and their own professional skills. They found the collegiality of the co-principalship energising and rewarding. The job did not take less of their time, but they were spending it differently, talking decisions over with a colleague rather than mulling them over alone. Sharing input from two (or more) people - their observations, conversations and general contact with staff and students - allowed co-principals to have an enhanced knowledge of their students' learning needs and a better understanding of the professional development needs of their staff. By constantly talking things over, they were able to be more reflective, and therefore probably more effective, school leaders.

For all co-principals in the study, sharing the leadership of their schools had been instrumental in reducing the stress and loneliness of the job. Instead of coping alone, they had someone to talk things over with, a colleague who understood the context of their problems and could make insightful contributions. For some of the women co-principals in the study, too, being in a co-principalship meant they did not have to sacrifice family life in order to be successful.

\section{Government Priorities}

The Government has shown its commitment to the professional development of principals through its induction courses for first-time principals: its Lead Space website; its Think.com web-based "educational environment" and principal's electronic network initiatives; its "laptops for principals" programmes and "Productive Partnerships" agreement with the principals' professional organisations; and its principals' focus groups and professional development centres. These provide a multitude of ongoing opportunities for principals to get assistance and advice. However, the value, the potential and even the existence of co-principalships has yet to be properly acknowledged. Principals and boards of trustees need to be better informed about shared school leadership initiatives. They could be the focus of study and discussion during professional development programmes. The Ministry of Education, too, could be encouraged to work towards developing guidelines for schools investigating shared leadership options, rather than discouraging them (as happens at present), and become more accepting of alternatives to the "single line of accountability" model.

As Wylie observed:

[there is a] disparity between the current public sector model of management, based on contractual hierarchical relationships, and what actually works at the school level in terms of a partnership between professional and trustees, and in terms of the dominance of administration in principals' workloads at what may be the expense of the core work of the school, children's learning. (1997a, p. 137)

\section{Concluding Remarks}

I have argued that a managerialist construct of leadership has been promoted by the New Zealand Ministry of Education and the Education Review Office since school administration became decentralised following the Tomorrow's Schools reforms of 1989. This approach to school leadership has been at odds not only with the beliefs and preferred practice of the majority of New Zealand primary school principals, but also with the recommendations of a wealth of national and international educational researchers and theorists.

By way of contrast, collaborative management structures are not only an effective way of leading successful schools, but may attract into school leadership a wider variety of applicants. At a time when principals are under increasing pressure, and a shortage of principals appears imminent (Brooking et al., 2003) alternative models of school principalship which might make the job more manageable and attractive need to be explored thoroughly. Co-principalships offer several advantages, including better decision making, increased job satisfaction and reduced stress.

I would argue that if the option of moving into a co-principalship was more accessible, more people would be attracted into principalship, and older, more experienced principals would be encouraged to stay in the job longer. In particular, the job would become more manageable for women with family commitments, who comprise a large proportion of the pool of potential school principals. 
Notes

1. Some of the reasons for this lack of women in leadership positions in schools include: the hierarchical structure of school leadership, the masculinist construct of a principal's leadership, social conditioning of women (and men), gender discrimination, commitment to classroom teaching, organisational culture, and there are many others. They are discussed in the following references: Acker, 1989; Apple \& Casey, 1989; Blackmore, 1993a, 1993b, 1995; Brooking et al., 2003; Court, 1994: Cunnison, 1989: Giles, 1995; Grant, 1989; Hall, 1993; Limerick, 1995; Lingard, 1995; Lingard \& Limerick, 1995; Luke, 1993; McMaster \& Randell, 1995; McMullan, 1993; Neville, 1988; Norman, 1985; Oram, 1989; Ouston, 1993; Ozga \& Walker, 1995; Pringle \& Timperley, 1995; Riehl \& Lee, 1996; Schmuck, 1987; Scrivens, 1997; Shakeshaft, 1987; Still, 1995; Strachan, 1997.

2. For example: Blase \& Blase, 1997; Brooker et al., 1998; Capper, 1994; Clift et al., 1995; Craig, 1992; Fullan, 1995; Germyn, 1992; Grace, 1995; Jenkins, 1995; Limerick \& Cranston, 1998; Macbeath \& Mortimer, 2001; Reinhart et al., 1998; Ross, 1992; Sackney \& Dibski, 1995; Senge, 1993; Sergiovanni, 2001)

\section{References}

Aiken, S. (1994). Appraisal: A process of control or development? Unpublished Masters thesis, Victoria University of Wellington.

Acker, S. (1989). Rethinking teachers' careers. In S. Acker (Ed.), Teachers, gender and careers (pp. 7-20). London: Falmer Press.

Al-Khalifa, E. (1989). Management by halves: Women teachers and school management. In H. deLyon, \& F. Mignuolo (Eds.), Women teachers: Issues and experiences (pp. 83-96). Milton Keynes: Open University Press.

Apple, M. \& Casey, K. (1989). Gender and the conditions of teachers' work. In S. Acker (Ed.), Teachers, gender and careers (pp. 171-186) London: Falmer Press.

Barnett, D., McKowen, C., \& Bloom, G. (1998). A school without a principal. Educational Leadership, 55(7), 48-49.

Bell, E. (2001). School's principal shortage: Fewer teachers want the job's growing challenges.

$<$ www.sfgate.com/cgi-bin/article.cgi?f=/chronicle/archive /2001/09/23/MN170314.DTL>
Blackmore, J. (1993a). "In the shadow of men" The historical construction of educational administration as a "masculinist" enterprise. In J. Blackmore \& J. Kenway (Eds.), Gender matters in educational administration: A feminist introduction (pp. 27-48). London: Falmer Press.

Blackmore, J. (1993b). Towards a "postmasculinist institutional politics"? In D. Baker \& M. Fogarty (Eds.), A gendered culture (pp. 75-93). Melbourne: Victoria University of Technology.

Blackmore, J. (1995). Breaking out from a masculinist politics of education. In B. Limerick \& B. Lingard (Eds.), Gender and changing educational management (pp. 44-56). Sydney: Hodder Education.

Blackmore, J. (1999) Troubling women: Feminism, leadership and educational change. Buckingham: Open University Press.

Blase, Jo., \& Blase, Joseph. (1997). Principals sharing school governance. Thousand Oaks, California: Corwin Press.

Brooker, R., Elliott, B., \& Macpherson, I. (1998). Changing Schools: Creating a discourse for teacher leadership. In L. Ehrich \& J. Knight (Eds.), Leadership in crisis? Restructuring principled practice (pp. 52-60). Flaxton, Queensland: Post Pressed.

Brooking, K. (2002). EEO in school: Good practice examples. Wellington: Ministry of Education.

Brooking, K., Collins, G., Court, M., \& O’Neill, J. (2003, in press). Getting below the surface of the principal recruitment crisis in New Zealand primary schools. Australian Journal of Educational Studies: Special Issue, Global Trends in Principal Recruitment, 42(2).

Brown, S., \& Feltham, W. (1997). Job sharing the principalship. $<$ www.naesp.org/comm/p0597b.htm >

Butterworth, G., \& Butterworth, S. (1998). Reforming education: The New Zealand experience 1984-1996. Palmerston North: Dunmore Press.

Capper, P. (1994). Participation and partnership: Exploring shared decision making in twelve New Zealand secondary schools, Part 1.Wellington: Post-Primary Teachers Association.

Cardno, C. (1990). Collaborative management in New Zealand schools. Auckland: Longman Paul. 
Clift, R., Veal, M., Holland, P., Johnson, M., \& McCarthy, J. (1995). Collaborative leadership and shared decision making: Teachers, principals and university professors. New York: Teachers College Press.

Codd, J. (1999). Educational reform, accountability and the culture of distrust. New Zealand Journal of Educational Studies, 34(1), 45-54.

Collins, G. (2002, August). Current issues and initiatives. New Zealand Principal, 23-25.

Court, M. (1994). Women transforming leadership. Massey University, Palmerston North: ERDC Press.

Court, M. (1998). Women challenging managerialism: Devolution dilemmas in the establishment of co-principalships in primary schools in Aotearoa/New Zealand. School Leadership and Management 18(1), 35-58.

Court, M. (2001). Sharingleadership in schools: Narratives of discourse and power. Unpublished DPhil Thesis, Massey University, Palmerston North.

Court, M. (2002). "Here there is no boss": Alternatives to the lone(ly) principal. set: Research information for Teachers, 3,17-21.

Court, M. (2003a, Spring). Different approaches to sharing school leadership: A full international practitioner enquiry report for the National College for School Leadership, Nottingham, UK. $<$ www.ncsl.org.uk/researchassociates > pp. 1-45.

Court, M. (2003b, in press). Towards democratic leadership: Co-principal initiatives. International Journal of Educational Leadership.

Court, M. (2003c, Summer, in press). Negotiating and reconstructing gendered leadership discourses: Leading and managing. Journal of the Australian Council for Educational Administration.

Craig, C. (1992). Collaboration: A way of "leading out". In C. Webber, B. Bosetti \& F. Johnson (Eds.), Trends in educational leadership (pp. 25-32). Calgary: University of Calgary.

Cromwell, S. (2002). Two principals lead one school. $<$ www.education-world.com/a_admin/admin269.shtml >

Cunnison, S. (1989). Gender joking in the staffroom. In S. Acker (Ed.) Teachers, gender and careers (pp. 151-167). London: Falmer Press.
Curry, B. (2000). Women in power: Pathways to leadership in education. Columbia University, NY: Teachers College Press.

Curtis, P. (2002). Vacant headteacher posts increase. <education.guardian.co.uk/schools/story/0,5500,725701,00.html >

Department of Education. (1988). Administering for excellence: Effective administration in New Zealand (Picot Report). Wellington Government Printer.

Education Review Office (ERO). (1996). Professional leadership in primary schools. <www.ero.govt.nz/Publications/eers1996/96no7hl.htm>

Education Review Office. (2001). The appointment of school principals. <www.ero.govt.nz/Publications/pubs2001/ApptPrincipals.htm>

Education Review Office. (2002). Good practices in principals' appraisal <www.ero.govt.nz/Publications/pubs2002/PrincipalsAppraisal.htm>

Eggert, D. (2002). Overwhelmed by support, Mercer Island principal stays $<$ seattlepi.nwsource.com/local/63013_principal20.shtml >

Flockton, L. (2002). Insights and oversights. $<w w w \cdot t h e s c h o o l d a i l y . c o m / a r t i c l e V i e w \cdot a s p$ ?articlePK $=16207>$

Fullan, M. (1995). The evolution of change and the new work of the educationalleader. In K. C. Wong \& K-M. Cheng(Eds.), Educational leadership and change: An international perspective (pp. 15-27). Hong Kong: Hong Kong University Press.

Germyn, C. (1992). Teacher as leader. In C. Webber, B. Bosetti \& F. Johnson (Eds.), Trends in educational leadership (pp. 42-52). Calgary: University of Calgary.

Giles, P. (1995). Educational administration and gender messages. In B. Limerick \& B. Lingard (Eds.), Gender and changing educational management (pp. 203-208). Sydney: Hodder Education.

Glenny, M., Lewis, D. \& White, C. (1997). Two at the top: Power sharing at Selwyn College. set: Research Information for Teachers, No. 1, Item 10, pp. 1-4.

Glynn, J. (2002).

$<$ www.ch.steiner.school.nz/administration/frames/admin.html>

Gonzalez, B. (2003). 12 schools in Poway to get new principals. <www.signonsandiego.com/news/education/ 20030313-9999 1mi13powskul.html> 
Grace, G. (1993). On the study of school leadership: Beyond education management. British Journal of Educational Studies, 41(4), 353-365.

Grace, G. (1995). School Leadership: Beyond educational management. London: The Falmer Press.

Grant, R. (1989). Women teachers' career pathways: Towards an alternative model of career. In S. Acker (Ed.), Teachers, gender and careers (pp. 35-50). London: Falmer Press.

Gronn, P. (2002). Distributed leadership. In K. Leithwood (Ed.), Second international handbook of educational leadership and administration (pp. 653-696). Dordrecht, Boston: Kluwer Academic.

Hall, V. (1993). Women in educational management: A review of research in Britain. In J. Ouston (Ed.), Women in educational management. Harlow: Longman.

Hall, V. (1997). Women in educational management. In M. Crawford, L. Kydd \& C. Riches (Eds.), Leadership and teams in educational management ( pp. 65-79). Buckingham: Open University Press.

Hopkins, G. (2003). From the Principal Files: The principal shortage - what can schools do to attract a new generation of school leaders? <www.education-world.com/a admin/admin197a.shtml>

Jenkins, H. O. (1995). School principals - entrepreneurial professionals In K. C. Wong \& K-M. Cheng (Eds.), Educational leadership and change: An international perspective (pp. 233-246). Hong Kong: Hong Kong University Press.

Keeler, B. (1998). Elementary co-principal named. <www.poconorecord.com/1998/local/tdo23549.htm>

Kim, G. (2001). Co-principal in running for national honour. $<$ seattletimes.nwsource.com/html/localnews/ 134300231_principal28m.html>

Laughlin, S. (2002). Fractal collaboration. $<$ home.bluemarble.net/ laughlin/ISDCLink/res-fractal.html>

Limerick, B. (1995). Accommodated careers: Gendered career paths in education. In B. Limerick \& B. Lingard (Eds.), Gender and changing educational management (pp. 68-78). Sydney: Hodder Education.

Limerick, B. \& Cranston, N. (1998). Engendering leadership: Reconceptualising our understandings. In L. Ehrich \& J. Knight (Eds.), Leadership in crisis? Restructuring principled practice (pp. 36-42). Flaxton, Queensland: Post Pressed.
Lingard, B. (1995). Gendered policy making inside the state. In B. Limerick \& B. Lingard (Eds.), Gender and changing educational management (pp. 136-149). Sydney: Hodder Education.

Lingard, B. \& Limerick, B. (1995). Thinking gender, changing educational management: An introduction. In B. Limerick \& B. Lingard (Eds.), Gender and changing educational management (pp. 1-10). Sydney: Hodder Education.

Livingstone, I. D. (1999). The workloads of primary teaching principals: A New Zealand survey. Wellington: Chartwell Consultants.

Luke, C. (1993). Women in higher education: Gendered discourse and cultural power. In D. Baker \& M. Fogarty (Eds.) A gendered culture (pp. 55-74). Melbourne: Victoria University of Technology.

Macbeath, J., \& Mortimer, P. (Eds.). (2001). Improving school effectiveness. Buckingham: Open University Press.

McMaster, M., \& Randell, S. (1995). Issues in changing the gendered culture of educational organisations. In B. Limerick \& B. Lingard (Eds.), Gender and changing educational management (pp. 57-66). Sydney: Hodder Education.

McMullan, H. (1993). Towards women-friendly schools. In J. Ouston (Ed.), Women in educational management. Harlow: British Educational Management and Administration Society.

Ministry of Education. (1990). Today's schools: A review of the education reform implementation process (Lough report). Wellington: Government Printer.

Ministry of Education. (2002, March). 2002 Teaching staff tables. <www.minedu.govt.nz/web/downloadable/dl7091_v1/staff.xls>

Neville, M. (1988). Promoting Women: Successful women in educational management. Auckland: Longman Paul.

Norman, H. (1985). The position of women in education. Teacher Career and Promotion Study. Wellington: Department of Education.

Nowlan, D. (2000). Leaders or managers: Principals in the twenty-first century. <www.ucalgary.ca/UofC/faculties/EDUC/jdnowlan>

O’Neill, John. (1999). Managing through teams. In M. Crawford, L. Kydd \& C. Riches (Eds.), Leadership and teams in educational management ( pp. 76-90). Buckingham: Open University Press. 
Oram, A. (1989). A master should not serve under a mistress: Women and men teachers 1900-1970. In S. Acker (Ed.), Teachers, gender and careers (pp. 21-34). London: Falmer Press.

Ouston, J. (1993). Women as managers. In J. Ouston (Ed.), Women in educational management. Harlow: British Educational Management and Administration Society.

Ozga, J., \& Walker, L. (1995). Women in educational management (theory and practice). In B. Limerick \& B. Lingard (Eds.), Gender and changing educational management (pp. 34-43). Sydney: Hodder Education.

Palmer, R. (1997). Getting a life: Principals and deputy principals reflect upon their changed career paths. Unpublished MEd Admin thesis, Massey University, Palmerston North.

Piggot-Irvine, E. (2003, February/March). Latest from NZPLC. New Zealand Principal and Leadership Centre.

Pringle, J., \& Timperley, H. (1995). Gender and educational management in New Zealand: Cooption, subversion or withdrawal? In B. Limerick \& B. Lingard (Eds.), Gender and changing educational management (pp. 162-173). Sydney: Hodder Education.

Rae, K. (1999, December). Viewpoint: Reforming education - was this indeed "The" New Zealand experience? New Zealand Journal of Educational Administration, 14, 1-4.

Reinhart, J., Short, P., Short, R., \& Eckley, M. (1998). Teacher empowerment and principal leadership: Understanding the influence process. Education Administration Quarterly, 34, (Supplemental), 630-649.

Riehl, C., \& Lee, V. (1996). Gender, organizations and leadership. In K Leithwood, J. Chapman, D. Corson, P. Hallinger \& A. Hart (Eds.) International handbook of educational leadership and administration, Vol 1 (pp. 873-919). London: Kluwer.

Robertson, J. M. (1995). Principals' partnerships: An action research study on the professional development of New Zealand school leaders. Unpublished DPhil thesis, University of Waikato, Hamilton.

Ross, M. (1992). Leadership synergy. In C. Webber, B. Bosetti \& F. Johnson (Eds.), Trends in educational leadership (pp. 3-14). Calgary: University of Calgary.
Rourou. (2001, May 7) The principal: Always under the spotlight. Rourou, 12(4), 7.

Sackney, L., \& Dibski, D. (1995). School based management: Will it fly? In K. C. Wong \& K-M. Cheng (Eds.), Educational leadership and change: An international perspective (pp. 29-42). Hong Kong: Hong Kong University Press.

San Francisco United School District website. (1996). The District's only teacher run school.

<www.sfusd.k12.ca.us/schwww/sch493/teacher_run.html >

Schmuck, P. (1987). Introduction. In P.Schmuck(Ed.), Womeneducators: Employees in schools in western countries (pp. 1-17). Albany: State University of New York Press.

Scrivens, C. (1997). Leadership in early childhood: The kindergarten experience. New Zealand Journal of Educational Administration, 12, 36-43.

Senge, P. (1993). The fifth discipline: The art and practice of the learning organisation. London: Century Business.

Sergiovanni, T. (1989). Mystics, neats and scruffies: Informing professional practice in educational administration. Journal of Educational Administration, 27(2), 7-21.

Sergiovanni, T. (1991). The principalship: A reflective practice perspective. Boston: Allyn and Bacon.

Sergiovanni, T. (2001). The principalship: A reflective practice perspective (4th ed.). Boston: Allyn and Bacon.

Shakeshaft, C. (1987). Women in educational administration. Newbury Park, CA: Sage.

Smulyan, L. (2000). Balancing acts: Women principals at work. Albany: State University of New York Press.

Snook, I. (1990). The principal: Manager or professional leader? New Zealand Principal, 5(1), 5-7.

Stewart, D. (2000). Tomorrow's principals today. Massey University, Palmerston North: Kanuka Grove Press.

Stewart, K. (2002). Two at the top. New Zealand Education Gazette, 81, 9. 
Still, L. (1995). Women in management: Glass ceilings or slippery poles? In B. Limerick \& B. Lingard (Eds.), Gender and changing educational management (pp. 106-120). Sydney: Hodder Education.

Strachan, J. (1997). Feminist educational leadership in a "new right" context in Aotearoa/New Zealand. Unpublished DPhil thesis, University of Waikato, Hamilton.

Sullivan, K. (1993). The myth of partnership: Educational reform and teacher disempowerment, New Zealand Annual Review of Education, 2, 151-165.

Sullivan, K. (1994). The impact of educational reform on teachers' professional ideologies. New Zealand Journal of Educational Studies, 29(1), 3-20.

Sutton, M. (2003, March 14). NZ short on principals. Waikato Times.

Thurman, R. (1969, May). The principal must be replaced. Educational Leadership, Supplement, pp. 778-783.

Trenberth, L. (1996). Principals, deputy principals and work stress: The role of coping and leisure. Unpublished DPhil thesis, Massey University, Palmerston North.

Upsall, D. (2003). Shared principalship of schools: A way to control workload and reduce stress? Unpublished MEd thesis, Victoria University of Wellington.

West, E. (2003). Winning patterns. New Zealand Education Gazette, 82, 12.

Wolffe, D. (2001). Bethel immersion school gets Yupik, English principals. $<$ www.peninsulaclarion.com/stories/091601/ ala_091601ala0170001.shtml >

Wylie, C. (1989). The impact of Tomorrow's Schools in primary schools and intermediates: 1989 survey report. Wellington: New Zealand Council for Educational Research.

Wylie, C. (1991). The impact of Tomorrow's Schools in primary schools and intermediates: 1990 survey report. Wellington: New Zealand Council for Educational Research.

Wylie, C. (1992). The impact of Tomorrow's Schools in primary schools and intermediates: 1991 survey report. Wellington: New Zealand Council for Educational Research.
Wylie, C. (1994). Self managing schools in New Zealand: The fifth year. Wellington: New Zealand Council for Educational Research.

Wylie, C. (1997a). Self managing schools seven years on: What have we learnt? Wellington: New Zealand Council for Educational Research.

Wylie, C. (1997b). At the centre of the web: The role of the New Zealand primary school principal within a decentralised education system. Wellington: New Zealand Council for Educational Research.

Wylie, C. (1999). Ten years on: How schools view educational reform. Wellington: New Zealand Council for Educational Research.

\section{The author}

Debby Upsall completed her Master of Education in 2003 after 5 years part-time study and this year is working full-time as a junior class teacher at Pukeatua School in Wainuiomata. Her teaching experience includes several years at the Correspondence School, working in Special Education; several years at an area school; three at an intermediate school; one year at a small country school, Reading Recovery tutoring and one year teaching English in Japan. 